H.M. Mallikarjuna

Department of Mechanical Engineering Government Engineering College K.R. Pet

C. Siddaraju

Department of Mechanical Engineering Ramaiah Institute of Technology Bengaluru India

H.S. Sunil Kumar

Department of Mechanical Engineering Smt L.V. Government Polytechnic Hassan India

Praveennath G. Koppad
Department of Mechanical Engineering
Dayananda Sagar College of Engineering
Bengaluru
India

\section{Nanohardness and Wear Behavior of Copper-SiC-CNTs Nanocomposites}

This study highlights the influence of carbon nanotubes (CNT) and silicon carbide (SiC) particles on microstructure, nanohardness and tribological behavior of copper nanocomposites. All the samples were fabricated via conventional powder metallurgy process involving high-energy ball milling, consolidation, sintering and hot forging. Microstructure of copper matrix composites was analyzed using both Transmission and Scanning Electron Microscope along wtih X-ray diffraction that was used to study the dispersion, bonding of reinforcements with matrix and identify the different phases formed during fabrication. Nanoindentation test was conducted to obtain nanohardness as a function of multiple reinforcement's content. Sliding wear test in dry conditions was conducted using pin-on-disc tribometer as per ASTM G99 standards. SEM microstructure revealed uniform dispersion of CNTs and SiC particles in the copper, which led to significant improvement in nanohardness. Nanocomposite with $3 w t . \%$ CNTs had nanohardness of $1.82 \mathrm{GPa}$ while pure copper had $0.94 \mathrm{GPa}$ indicating significant improvement. The tribological test showed that nanocomposites had excellent wear resistance in comparison with pure copper.

Keywords: Carbon nanotubes; Powder Metallurgy; Hardness; Wear.

\section{INTRODUCTION}

Carbon nanotube which is an allotrope of carbon was discovered by Sumio Iijima in the year 1991 [1]. Studies on carbon nanotubes revealed that they possess excellent mechanical, thermal and electrical properties. Several experimental studies showed that CNTs possess high strength of $63 \mathrm{GPa}$ and elastic modulus close to 1 $\mathrm{TPa}$. These properties are useful in enhancing load bearing capacity of any matrix material for structural applications $[2,3]$. On the other hand, the thermal property like thermal conductivity is $3000 \mathrm{~W} / \mathrm{m}^{-\mathrm{K}}$ which is extremely high when compared to other materials and possess zero coefficient of thermal expansion [4]. Latest developments in the area of synthesis helps in development of high quality and large quantity of CNTs using arc discharge method, dual-pulsed laser, catalyzed chemical vapor deposition and ball milling techniques $[5,6]$. Since then most of the researchers across the world have dedicated themselves to make use of their excellent properties by reinforcing into ceramic, plastic and metal matrices to develop nanocomposites [7-9]. Copper is widely used metal next to aluminum in various industries due to its high electrical conductivity. Copper possess high thermal conductivity (400 W/mK) and electrical conductivity $(58.0 \mathrm{MS} / \mathrm{m}$; resistivity: $16.70 \mathrm{n} \Omega . \mathrm{m})$ at $20^{\circ} \mathrm{C}$. Thus copper is an ideal metal where electrical and thermal conductivity is essential in industrial applications. However, copper is a ductile metal which possesses low strength and low wear resistance in comparison with ferrous metals.

Received: May 2020, Accepted: June 2020

Correspondence to: Dr. H.M. Mallikarjuna

Department of Mechanical Engineering,

Government Engineering College, K.R. Pet, India

E-mail: mallikarjuna.hm@gmail.com

doi: $\mathbf{1 0 . 5 9 3 7 / f m e 2 0 0 3 6 8 8 M}$

(C) Faculty of Mechanical Engineering, Belgrade. All rights reserved
Literature survey reveals that many researchers have used carbon nanotubes as reinforcement for various metals $(\mathrm{Cu}, \mathrm{Al}, \mathrm{Mg}$ and $\mathrm{Ni})$ and ceramics $\left(\mathrm{SiC}, \mathrm{Si}_{3} \mathrm{~N}_{4}\right.$ and $\mathrm{Al}_{2} \mathrm{O}_{3}$ ) for developing nanocomposites. Cha et al. [10] adopted a new process which they termed as molecular level mixing process for developing $\mathrm{Cu} / \mathrm{CNT}$ nanocomposite. CNTs were uniformly distributed in copper matrix leading to an improvement of yield strength of the composite. The yield strengths of nanocomposite were 360 and $455 \mathrm{MPa}$ for 5 and $20 \mathrm{vol} . \%$ carbon nanotube while yield strength of pure copper was $150 \mathrm{MPa}$. Similarly, the elastic modulus of composite with 5 and 10 vol.\% CNT were 112 and $135 \mathrm{GPa}$, whereas for pure copper it was found to be $82 \mathrm{GPa}$.

Koppad et al. [11] developed $\mathrm{Cu} / \mathrm{CNT}$ nano-composite by combining powder metallurgy and hot forging. The SEM studies showed uniform distribution of carbon nanotube with good bonding between copper grains. The microhardness of pure copper was increased from $69 \mathrm{VHN}$ to $141 \mathrm{VHN}$ for nanocomposite with addition of 4 wt.\% carbon nanotube. Apart from carbon nanotubes, silicon carbide has also been added to copper to enhance wear resistance. The effect of reinforcement on mechanical or thermal property mainly depends on homogeneous distribution, and bonding between matrix and reinforcement. The homogenous distribution mainly depends on the type of mixing or blending process used and the other secondary processing techniques which could be extrusion, rolling or forging.Carbon nanotube and silicon carbide are both non-wetting with copper. In order to improve the bonding, electroless coating technique is used for copper coating on reinforcements. Coated reinforcements have good bonding between matrix and reinforcement that contributes to improving the mechanical and thermal property of the composite [12]. In our present work, CNT and $\mathrm{SiC}$ reinforced copper nanocomposites that were developed by powder metal- 
lurgy route. Microstructure, nanoindentation and dry sliding wear tests were carried out on nanocomposites to study the effect of multiple reinforcements.
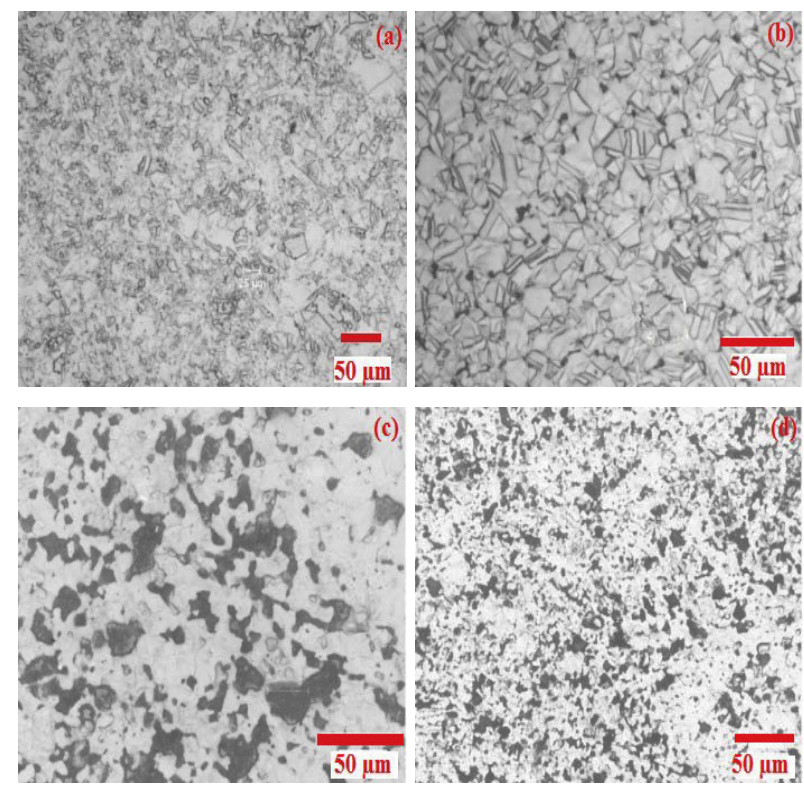

Figure 1. Optical microstructure image of (a) copper, (b) $\mathrm{Cu}$ 2CNT nanocomposites, (c) $\mathrm{Cu}-4 \mathrm{SiC}$ and (d) $\mathrm{Cu}-4 \mathrm{SiC}-4 \mathrm{CNTs}$

\section{EXPERIMENTATION}

\subsection{Materials}

CNTs possessing multiwalls (Purity: $99.5 \%$, Nanotube diameter: $10-40 \mathrm{~nm}$ and density: $2.1 \mathrm{~g} / \mathrm{cm}^{3}$ ) and $\mathrm{SiC}$ (purity: $99.5 \%$, particle size $15-40 \mu \mathrm{m}$, density: 3.21 $\mathrm{g} / \mathrm{cm}^{3}$ ) were selected as reinforcing phase to the composite. Electrolytic grade copper powder (Purity: $99.5 \%$ and density: $8.94 \mathrm{~g} / \mathrm{cm}^{3}$, Loba chemie Pvt. Ltd. India) was chosen as a matrix in the synthesis of hybrid composites.

\subsection{Fabrication}

CNTs and $\mathrm{SiC}$ were coated with electroless copper to get good bonding with copper matrix. Electroless method was adopted for copper coating on reinforcements [13].Copper coated CNTs and SiC were blended with copper powder using high-energy ball mill. For ball milling, planetary ball mill (Insmart Systems, Hyderabad, India) with stainless bowls of $250 \mathrm{ml}$ capacity and stainless steel balls of $12 \mathrm{~mm}$ diameter were utilized. CNTs content was varied between 1-4 wt.\% while $\mathrm{SiC}$ content was constant at $4 \mathrm{wt} \%$ for all composite samples. Composite powder was subjected to ball milling for about $3 \mathrm{~h}$ at $300 \mathrm{rpm}$ using ball to powder ratio of $8: 1$. The composite powder was compacted at pressure of $400 \mathrm{MPa}$ for $5 \mathrm{~min}$ in die using hydraulic press and sintered for $1 \mathrm{~h}$ at $900^{\circ} \mathrm{C}$. Subsequently compacted samples were re-sintered for ( $7 \mathrm{hrs})$ and hot forged for at $900^{\circ} \mathrm{C}$.

\subsection{Characterization}

Microstructure of copper and hybrid composite were studied using optical microscope, scanning electron microscope (SEM) (Make: JEOL 840A JSM) and
Transmission Electron Microscope (TEM). X-ray diffraction patterns were taken to identify the phases. Nanoindentation studies were conducted to assess the nanohardness at load of $100 \mathrm{mN}$. Room temperature sliding wear test was conducted using pin-on-disc machine (Make: Ducom TR20-LE, India) under dry conditions. Disc made up of EN-31 steel was selected as counterface material. The sliding velocity was kept constant at $0.6 \mathrm{~m} / \mathrm{s}$, while the normal load was varied from 10 to $50 \mathrm{~N}$. Worn surfaces of nanocomposites after wear test were analyzed using SEM.

\section{RESULTS \& DISCUSSION}

\subsection{Microstructural studies}

Fig. 1 shows the optical micrograph of both copper and its hybrid composites taken after hot forging. It is observed that copper possesses least amount of porosity which is found in between the grain boundaries. Both $\mathrm{CNT}$ and $\mathrm{SiC}$ particles were found to be homogeneously dispersed in copper matrix as shown in Fig. 1(b) - (d). Fig. 2 (a) - (d) shows SEM images of unreinforced copper and its $\mathrm{CNT} / \mathrm{SiC}$ reinforced hybrid composites. It is evident from the micrographs that hardly any porosity is observed and a good level of densification was achieved. Both the reinforcements had good bonding with the copper matrix with clean interface. The distribution of $\mathrm{SiC}$ was uniform throughout the copper matrix with no sign of agglomeration. In addition with the good densification both uniform distribution and good bonding of reinforcements inside the copper matrix was achieved successfully. Application of pressure under high temperature ensured closure of porosity in the sintered compacts, due to which no pores are visible in the microstructure as shown in Fig. 2 (a) - (d). This is very important from mechanical properties point of view because good bonding and minimal porosity helps in better and improved properties.
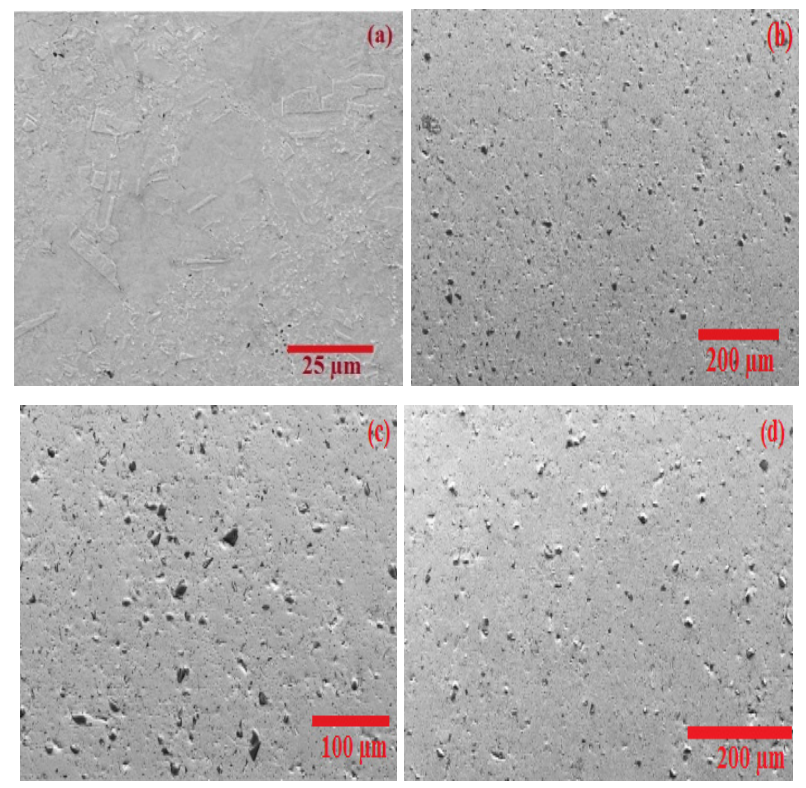

Figure 2. SEM micrographs of hot pressed (a) pure copper (b) $\mathrm{Cu}$ 4SiC-1CNTs (c) Cu-4SiC-2CNTs and (d) Cu-4SiC-3CNTs reinforced hybrid nanocomposite. 
Fig. 3 shows that TEM images of $\mathrm{Cu}-4 \mathrm{SiC}-4 \mathrm{CNTs}$ hybrid composite. It is observed that $\mathrm{SiC}$ particles and CNTs are present and dispersed uniformly in the copper matrix composite. The particle size of $\mathrm{SiC}$ and copper were reduced during high energy ball milling process and carbon nanotubes can be observed without damage after ball milling. If ball-milling time is increased, CNTs get damaged and broken into small fragments like graphite. With clear wall structure seen in TEM indicates no damages occurred to CNTs during ball milling or hot forging. The composites have high nanohardness and better wear resistance due high dislocation density generated around the reinforcements during the composite subjected to heavy deformation in hot pressing process.

\subsection{Nanoindentation studies}

The nanoindentation test was performed on all the hot pressed samples by applying a load of $100 \mathrm{mN}$.

$$
\text { Nanohardness }(\mathrm{H})=\left\{\mathrm{P} *\left(\mathrm{~h}_{\max }\right)\right\} /\left\{\mathrm{A}_{\mathrm{c}} *\left(\mathrm{~h}_{\max }\right)\right\}
$$

where $\mathrm{P}$ is load applied in $\mathrm{mN}$ and $\mathrm{A}_{\mathrm{c}}\left(\mathrm{h}_{\max }\right)$ is the area of contact between specimen and indenter. Load of 100 $\mathrm{mN}$ was chosen for better contact impression on all the samples. The nanohardness obtained from the test is shown in Fig. 5. It is observed that both the CNTs and $\mathrm{SiC}$ contribute to the strengthening of copper matrix. Compared to unreinforced copper there was $85 \%$ increase in nanohardness for $3 \mathrm{wt} . \%$ CNT reinforced copper hybrid composite. Significant improvement in the nanohardness of the hybrid composites is due to nucleation of dislocations at interface due to coefficient of thermal expansion mismatch between CNTs, SiC and copper.
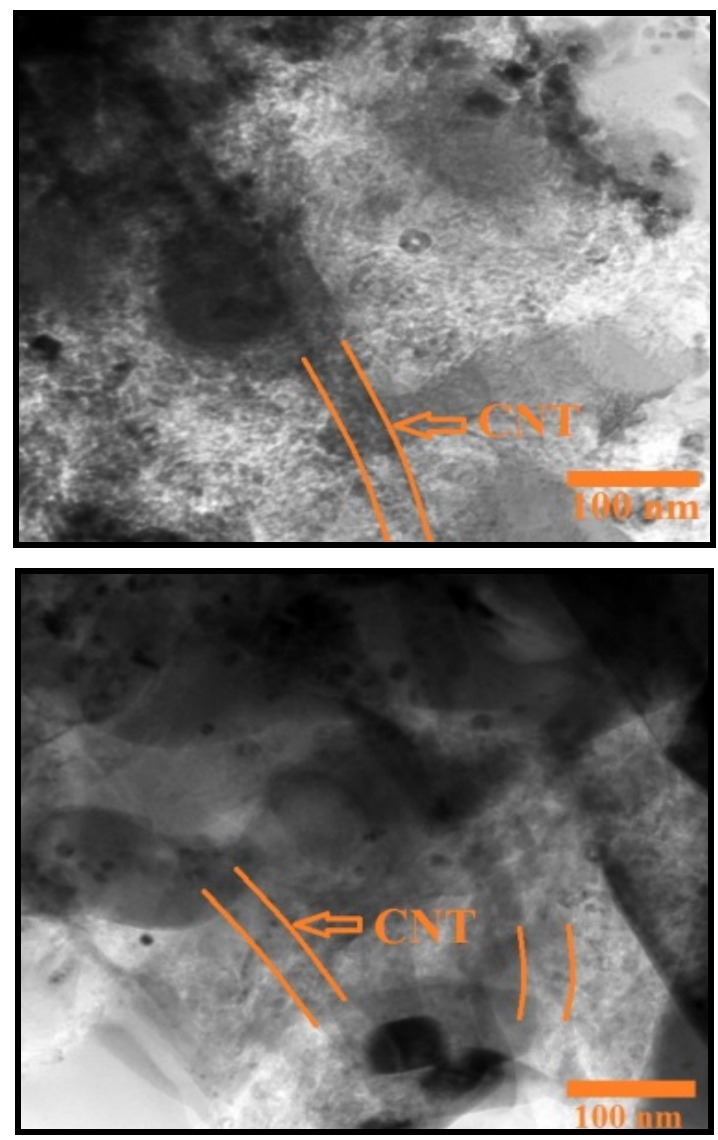

Figure 3. TEM images of $\mathrm{Cu}-4 \mathrm{SiC}-4 \mathrm{CNT}$ s nanocomposites
The formation of subgrain boundaries around CNTs and $\mathrm{SiC}$ due to dislocation accumulation, pile-ups and further evolution of them into numerous grain boundaries lead to improvement of hardness of hybrid nanocomposite. However hybrid nanocomposite with $4 \mathrm{wt} \%$ CNT dropped by $20 \%$ when compared to that of $3 \mathrm{wt} . \%$. This can due to the agglomerates of CNTs due to high weight fraction. The high concentration is due strong Vander Waal forces acting between nanotubes leading to the formation of agglomerates.

Fig. 4 (a) illustrates the XRD of hybrid nanocomposite. It is observed from the patterns that the three peaks of copper $(111,200,220)$, carbon and $\mathrm{SiC}$ were seen. Fig. 4 (b) represents the $\mathrm{Cu}-4 \mathrm{SiC}-3 \mathrm{CNT}$ nanocomposite. The patterns showed similar peaks of copper, $\mathrm{SiC}$ and carbon as seen in the previous pattern. The presence of small $\mathrm{C}$ and $\mathrm{SiC}$ peaks could be due to their small content. Further no additional peak was seen in the patterns from which it can be conferred that there was no interfacial reactions between copper and carbon.
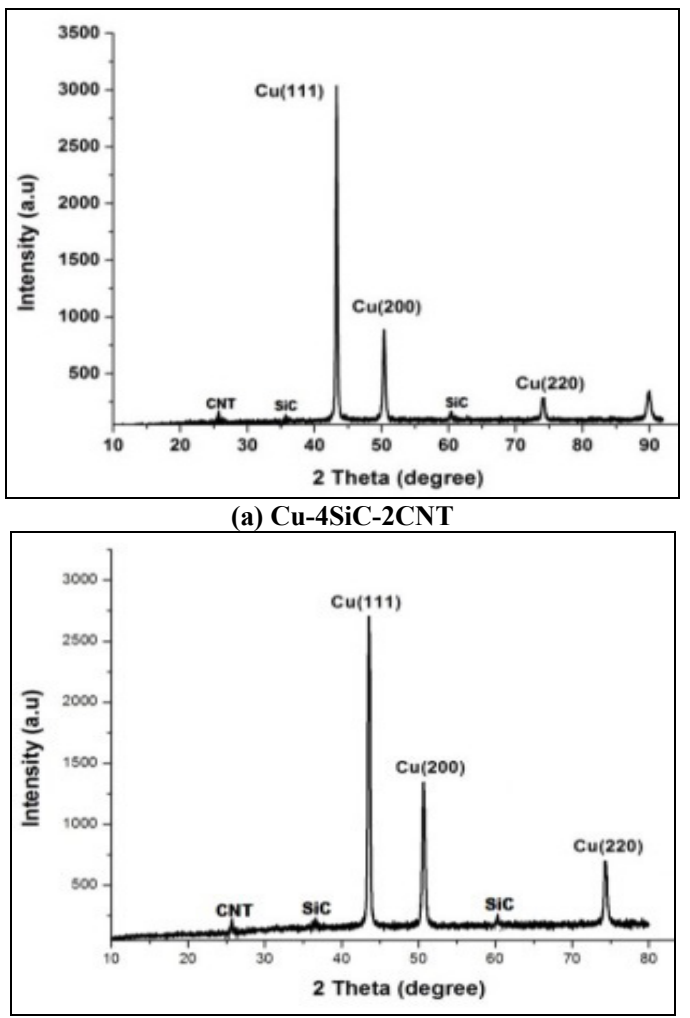

(b) $\mathrm{Cu}-4 \mathrm{SiC}-3 \mathrm{CNT}$

Figure 4. XRD pattern of nanocomposites

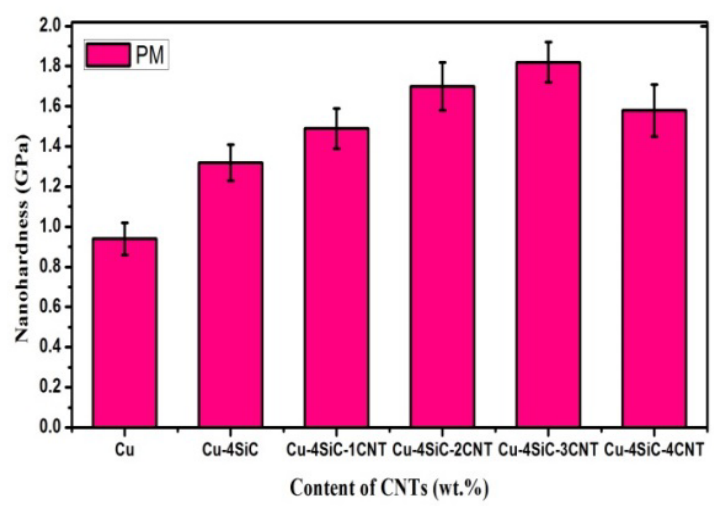

Figure 5. Nanohardness of copper, $\mathrm{Cu}-4 \mathrm{SiC}$ and $\mathrm{Cu}-4 \mathrm{SiC}-\mathrm{CNTs}$ hybrid composites with different $\mathrm{CNTs}$ content 


\subsection{Wear behaviour}

Wear rate of unreinforced copper and its hybrid composites with respect to varying normal load and fixed sliding velocity of $0.6 \mathrm{~m} / \mathrm{s}$ is presented in Fig. 6 . It is observed that wear resistance of hybrid composites significantly improves as the content of CNT (up to 3 wt.\%) increases.

Due to addition of both reinforcements with varying CNT content, hybrid composites showed profound increase in wear resistance. Enhanced wear resistance of $\mathrm{CNT} / \mathrm{SiC}$ reinforced hybrid composites compared to unreinforced copper is attributed to the following strengthening mechanisms. First, by virtue of high hardness of $\mathrm{SiC}$ and extraordinary properties of CNTs high hardness is imparted to the hybrid composites [14]. The $\mathrm{SiC}$ particles tend to improve the hardness of hybrid composites by virtue of its high hardness. Likewise, CNTs improve the strength of copper matrix due to outstanding modulus and strength. It is well known that the increase in hardness is inversely proportional to the wear coefficient. Present work is in line with the Archard's law where wear resistance increased with the increase in hardness. Due to high hardness, all the hybrid composites displayed high resistance to plastic deformation thereby contributing to wear resistance. Secondly, the better load bearing capacity of these reinforcements due to good bonding ensures efficient load transfer from copper to CNTS and SiC. During wear test the SiC particles and CNTs protrude out of copper matrix and ensure that there is no direct contact with the counterface disc. Along with this, even if there is a contact between the two mating surfaces, then most of the load is transferred to the reinforcements ensuring that copper matrix suffers from minimal weight loss. Lastly, the formation of carbon rich lubricating layer helps to avoid direct metal-to-metal contact. During wear the walls of CNTs smear away and get mixed with the other wear debris. As the test progresses the amount of carbon collected in the wear debris from CNTs will increase. Due to this a thin lubricating layer of carbon is formed on the hybrid composite pin surface $[15,16]$. This layer avoids the metal to metal contact between the mating surfaces and reducing the adhesion, thereby reducing the weight loss.

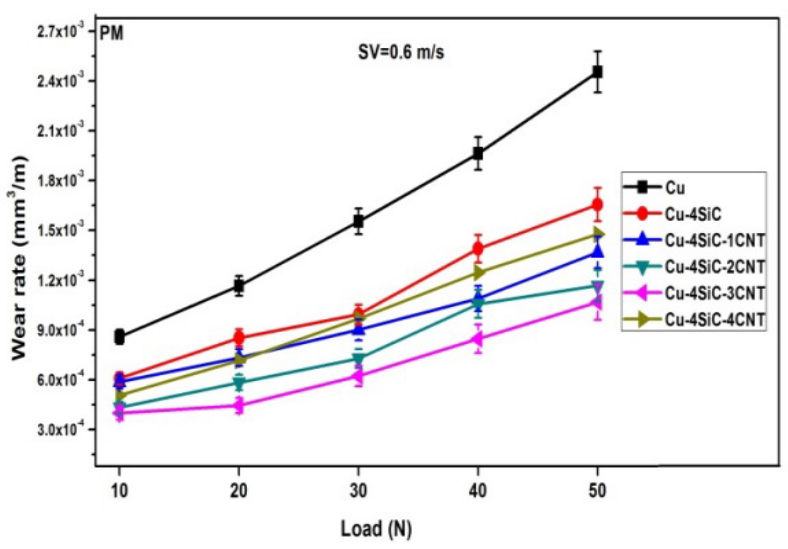

Figure 6. Wear rate of copper and its nanocomposites with varying load and fixed sliding velocity of $0.6 \mathrm{~m} / \mathrm{s}$

However the wear rate of all materials was found to increase as the normal load was increased. Out of all, pure copper suffered highest weight loss for all cases of load. As the normal load was increased from 10 to $50 \mathrm{~N}$, the extent of plastic deformation and adhesion will be high, which enhances higher wear rates in all materials. For pure copper the maximum wear rate of $2.5 \times 10^{-3}$ $\mathrm{mm}^{3} / \mathrm{m}$ was recorded at $50 \mathrm{~N}$ load test, which is higher than hybrid composites. Highest wear resistance was obtained for $\mathrm{Cu}-4 \mathrm{SiC}-3 \mathrm{CNT}$ hybrid composite for load conditions and compared to all samples. Overall, important point to be noted is that the when the normal load in increased there is a subsequent increase in wear rate of both unreinforced copper and hybrid composites, which is attributed to peeling of lubricating layer from the surface of pin.

\section{CONCLUSION}

CNTs and SiC reinforced copper hybrid composites were successfully developed by combining ball milling and hot forging. The developed hybrid composites had good density with minimal porosity and good distribution of both reinforcements. The interfacial bonding was significant due to copper coating provided on the surface of MWCNTs and SiC. The nanohardness was found to increase significantly due to the addition of CNTs and SiC. The nanohardness of $\mathrm{Cu}-4 \mathrm{SiC}-3 \mathrm{CNT}$ composite was $1.82 \mathrm{GPa}$ which is almost double the value of pure copper $(0.94 \mathrm{GPa})$. With the increase in CNT content, material loss in hybrid composites was found to decrease. The maximum wear rate of $2.5 \times 10^{-3}$ $\mathrm{mm}^{3} / \mathrm{m}$ was recorded for pure copper at $50 \mathrm{~N}$ load while minimum wear rate of $1.05 \times 10^{-3} \mathrm{~mm}^{3} / \mathrm{m}$ was recorded for $3 w t . \%$ CNT reinforced hybrid composite. This is attributed to lubricating effect induced by uniformly dispersed CNTs and formation of carbon rich lubricating layer.

\section{REFERENCES}

[1] Iijima, S.: Helical microtubules of graphitic carbon, Nature, Vol. 354, pp. 56-59, 1991.

[2] Yu, M.F., Lourie, O., Dyer, M.J., Moloni, K., Kelly, T.K. and Ruoff, R.F.: Strength and breaking mechanism of multiwalled carbon nanotubes under tensile load, Science, Vol. 287, pp. 637-640, 2000.

[3] Kashyap, K.T., Koppad, P.G., Puneeth, K.B., Ram, H.R.A. Mallikarjuna, H.M.: Elastic modulus of multiwalled carbon nanotubes reinforced aluminium matrix nanocomposite - A theoretical approach, Comput. Mater. Sci., Vol. 50, pp. 2493-2495, 2011.

[4] Kim, P., Shi, L., Majumdar, A. and McEuen, P.L.: Thermal transport measurements of individual multiwalled nanotubes, Phys. Rev. Lett., Vol. 87, pp. 215502, 2001.

[5] Kaufmann, C.G., Zampiva, R.Y.S., Bergmann, C.P., Alves, A.K., Mortari, S.R., Pavlovic, A.: Production of multi-wall carbon nanotubes starting from a commercial graphite pencil using an electric arc discharge in aqueous medium, FME Trans., Vol. 46, pp. 151-156, 2018.

[6] Rao, R. et al.: Carbon nanotubes and related nanomaterials: Critical advances and challenges for 
synthesis toward mainstream commercial applications, ACS Nano, Vol. 12, pp. 11756-11784, 2018.

[7] Koppad, P.G., Singh, V.K., Ramesh, C.S., Koppad, R.G., Kashyap, K.T.: Metal matrix nanocomposites reinforced with carbon nanotubes, In: Tiwari, A., Shukla, S.K. (Eds.): Advanced Carbon Materials and Technology, John Wiley \& Sons, Inc., Hoboken, pp. 331-376, 2013.

[8] Karimi, N.Z., Heidary, H., Yousefi, J., Sadeghi, S. and Minak, G.: Experimental investigation on delamination in nanocomposite drilling, FME Trans., Vol. 46, pp. 62-69, 2018.

[9] Peigney, A., Laurent, C., Flahaut, E., Rousset, A.: Carbon nanotubes in novel ceramic matrix nanocomposites, Ceram. Int., Vol. 26, pp. 677-683, 2000.

[10] Cha, S.I., Kim, K.T., Arshad, S.N., Mo, C.B. and Hong, S.H.: Extraordinary strengthening effect of carbon nanotubes in metal matrix nanocomposites processed by molecular level mixing, Adv. Mater., Vol. 17, pp. 1377-1381, 2005.

[11] Koppad, P.G., Kashyap, K.T., Shrathinth, V., Shetty, T.A. and Koppad, R.G.: Microstructure and microhardness of carbon nanotube reinforced copper nanocomposites, Mater. Sci. Technol., Vol. 29, pp. 605-609, 2013.

[12]Koti, V., George, R., Shakiba, A. and Murthy, K.V.S.: Mechanical properties of copper nanocomposites reinforced with uncoated and nickel coated carbon nanotubes, FME Trans., Vol. 46, pp. 623630, 2018.

[13]Chen, W.X. et al.: Tribological application of carbon nanotubes in a metal-based composite coating and composites, Carbon, Vol. 41, pp. 215222, 2003.

[14] Cikara, D., Rakin, M. and Todic, A.: Cast steel-SiC composites as wear resistant materials, FME Trans., Vol. 37, pp. 151-155, 2009.

[15] Scharf, T.W., Neira, A., Hwang, J.Y., Tiley, J. and Banerjee, R.: Self-lubricating carbon nanotube reinforced nickel matrix composites, J. Appl. Phys., Vol. 106, pp. 013508, 2009.

[16] Akbarpour, M.R., Alipour, S., Farvizi, M. and Kim, H.S.: Mechanical, tribological and electrical properties of $\mathrm{Cu}-\mathrm{CNT}$ composites fabricated by flake powder metallurgy method, Arch. Civ. Mech. Eng., Vol. 19, pp. 694-706, 2019.

\section{НАНОТВРДОЋА И ХАБАЊЕ НАНОКОМ- ПОЗИТА НА БАЗИ БАКРА ОЈАЧАНИХ СА SiC И CNT}

\section{Х.М. Маликарџуна, Ц. Сидараџу, Х.С.С. Кумар, П.Г. Копад}

Истражује се утицај угљеничних наноцеви (CNT) и честица силицијум карбида (CNT) на микроструктуру, нанотврдоћу и триболошко понашање нанокомпозита на бази бакра. Сви узорци су израђени конвенционалном техником прашкасте металургије: кугличним глодањем коришћењем велике енергије, консолидацијом, синтеровањем и топлим ковањем. Микроструктура бакарне матрице је испитана помоћу трансмисионог и скенирајућег електронског микроскопа уз дифракцију х-зрака за анализу дисперзије, везивање ојачања са матрицом и одређивање различитих фаза израде композита. Испитивање наноиндентације је вршено да би се добила нанотврдоћа као функција вишеструког садржаја ојачања. Испитивање хабања клизањем на суво је обављено на пин-он-диск трибометру према стандардима ASTM G99. Микроскопирање је показало да у микроструктури постоји равномерна дистрибуција CNT и $\mathrm{SiC}$ честица у бакру што је довело до значајног побољшања нанотврдоће. Нанокомпозит ca 3 теж.\% CNT је имао нанотврдоћу 1,82 GPa, док је код бакра нанотврдоћа била $0,94 \mathrm{GPa}$. Триболошка испитивања су показала да нанокомпозити имају изванредну отпорност на хабање у поређењу са чистим бакром. 